\title{
The Influence of Problem Based Learning, Guided Inquiry Learning Models Assisted by Lectora Inspire, and Scientific Attitudes to Student's Cognitive Values
}

\author{
Rahmadina Nasution ${ }^{1}$ \\ Program of Postgraduate, \\ Universitas Negeri Medan \\ Medan, Indonesia \\ email :
}

\author{
Saronom Silaban ${ }^{2}$ \\ Program of Postgraduate, \\ Universitas Negeri Medan \\ Medan, Indonesia
}

\author{
Ajat Sudrajat ${ }^{2}$ \\ Program of Postgraduate, \\ Universitas Negeri Medan \\ Medan, Indonesia
}

nasutionrahmadina192@gmail.com

\begin{abstract}
Chemistry is not taught simply by providing an understanding of meaning, facts, concepts, principles, but also an invention through a process of discovery with real action. This study aims to determine the Problem Based Learning (PBL) learning model assisted by the Lectora Inspire media, the Guided Inquiry (GI) learning model assisted by Lectora Inspire media, and students 'attitudes toward students' cognitive values on colloid system material. This research is a quasi-experimental study with a $2 \times 2$ factorial design. Data analysis techniques were two-way variant analysis (Anava) with a significance level of 0.05 . The results showed that there were no significant factors using the PBL assisted by the Lectora Inspire media with the GI assisted by Lectora Inspire media on colloid system material with a significance of 0.135 , high and low areas of expertise from other students with a significance of 0.000 , and the second model of learning does not show interaction with attitude categories in influencing students' cognitive value with a significance of 0.603 . So it can be concluded that both learning models and attitudes achieve cognitive values of students but do not interact with each other.
\end{abstract}

Keywords- problem based learning, guided inquiry, scientific attitudes, and cognitive values

\section{INTRODUCTION}

Chemistry is essentially a way of systematically finding out and understanding about nature. Chemistry is not taught simply by providing an understanding of understanding, facts, concepts, principles, but also an invention through the process of finding a real action [1]. The colloid system is one of the materials taught in chemistry [2]. Colloidal system material is very closely related to the problems that exist in everyday life. We have encountered many of the characteristics of the colloidal system in the fields of agriculture and medicine so that the material of the colloidal system becomes very important to be studied and understood, not just to be memorized [3].

There are several things that cause students' lack of interest in learning chemistry, namely: 1) Teaching and learning activities that are still less effective by teachers, because teachers lack link between problems in the surrounding environment with learning in school, 2) Learning models that are still focused the teacher as the main source of knowledge, 3 ) reflection and evaluation of the teacher's ability during the learning process and results is still less than optimal [4].

One way that can encourage students to be interested in learning colloidal material is to apply the Problem Based Learning (PBL) and Guided Inquiry (GI) learning models. PBL provides more opportunities for students to actively search for and process information themselves, build their own knowledge, and build meaning based on the experience gained. GI learning models can improve students' understanding of chemical concepts because in GI model learning students are directly involved in making observations, experiments and finding answers to the questions asked.

So that students' understanding of the material taught is more maximal it needs to be supported by appropriate media. In this research, Lectora Inspire media assistance was used. One of the benefits of using Lectora Inspire is that there are many templates for interactive learning media that can be selected [5].

The application of the Lectora Inspire media-assisted PBL and GI models is expected to increase the cognitive, and psychomotor values of students. One attitude that belongs to the affective domain is the scientific attitude. Scientific attitude is one aspect of learning outcomes belonging to the affective domain [5]. Scientific attitude means the willingness to understand and know, the ambition to question everything, collect data and ask its meaning, the desire to prove, think of results, consider the place and logic [6]. Attitudes toward learning that take place, in this case is a scientific attitude, can provide good motivation for students in learning.

The purpose of this study was to determine: (1) differences in cognitive values of students who were taught using PBL learning models assisted by Lectora Inspire media with the GI learning model assisted by Lectora Inspire media on colloidal 
system material; (2) differences in the influence of high and low scientific attitude categories on students' cognitive values on colloidal system material; (3) the interaction between the two learning models with the categories of scientific attitudes in influencing students' cognitive values.

\section{RESEACH METHODS}

The form of research design used for the interaction of the two learning models with scientific attitudes is the Factorial Design $2 \times 2$ as shown in Table 1 .

TABLE 1. Design Of Learning Models With Scientific Attitudes

\begin{tabular}{|c|c|c|}
\hline \multirow[b]{2}{*}{$\begin{array}{c}\text { Scientific } \\
\text { attitude (B) }\end{array}$} & \multicolumn{2}{|c|}{ Learning Models } \\
\hline & $\begin{array}{c}\text { Problem Based } \\
\text { Learning with Lectora } \\
\text { Inspire assisted } \\
\left(A_{1}\right)\end{array}$ & $\begin{array}{l}\text { Guided Inquiry with } \\
\text { Lectora Inspire assisted } \\
\left(\mathrm{A}_{2}\right)\end{array}$ \\
\hline High $\left(B_{1}\right)$ & $\mathrm{A}_{1} \mathrm{~B}_{1}$ & $\mathrm{~A}_{2} \mathrm{~B}_{1}$ \\
\hline Low $\left(\mathrm{B}_{2}\right)$ & $\mathrm{A}_{1} \mathrm{~B}_{2}$ & $\mathrm{~A}_{2} \mathrm{~B}_{2}$ \\
\hline
\end{tabular}

This research is in the form of quantitative research where to obtain quantitative data used data collection tools in the form of tests and non-tests. Data were analyzed using two-way variant analysis technique (Twoway ANAVA) using SPSS 24.0 for Windows.

\section{RESULT AND DISCUSSION}

Before being given treatment, at the beginning of the meeting all students were given a pretest to find out the students' initial abilities about colloidal system material. Description of the initial ability data of the two classes in the colloidal system material is shown in Table 2 .

TABLE 2. Description Of Pretest Data Based On Learning Model In Experimental Class I And Experimental Class Ii

\begin{tabular}{ccccccc}
\hline Group & & N & Min & Max & Mean & Std. Deviation \\
\hline Eks I & Pretest & 31 & 30 & 65 & 45.81 & 9.755 \\
\hline Eks II & Pretest & 31 & 40 & 70 & 55.16 & 7.470 \\
\hline
\end{tabular}

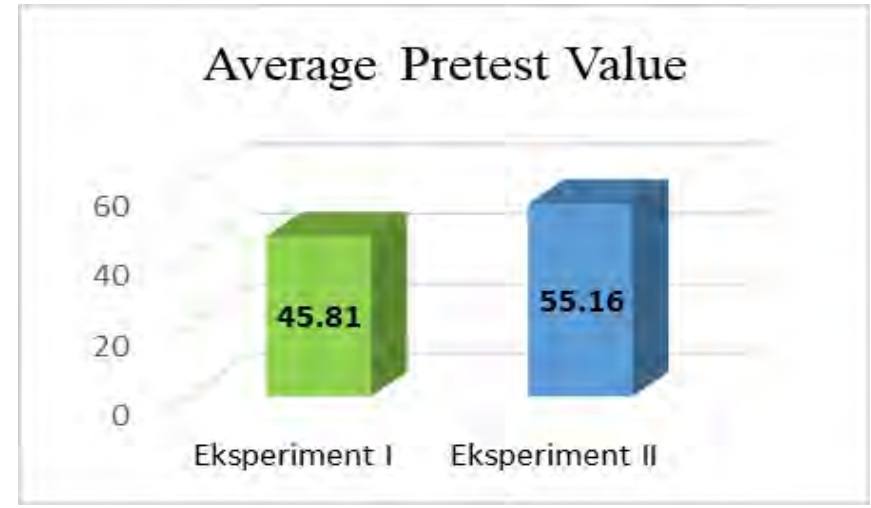

Fig 1. Average Student Pretest Value

Based on Table 4.1 shows that the students' initial knowledge about the material of the colloidal system before being given treatment, for the experimental class I the average pretest score was 45.81 and the highest score was 65 and the lowest value was 30 . Whereas for the experimental class II the average value was obtained pretest of 55.16 with the highest score of 70 and the lowest score of 40 .

Furthermore, the two classes were given different treatments, namely, for the experimental class I was taught with the Lectora Inspire assisted PBL model while the experimental class II was taught with the Lectora Inspire assisted GI model. At the end of the meeting after all the material is taught, students are given a posttest to find out the learning outcomes. Description of the posttest result data of the students of both classes can be seen in Table 3 .

TABLE 3. Description Of Posttest Data Based On Learning Models In Experimental Class I AND EXPERIMENTAL CLASS II

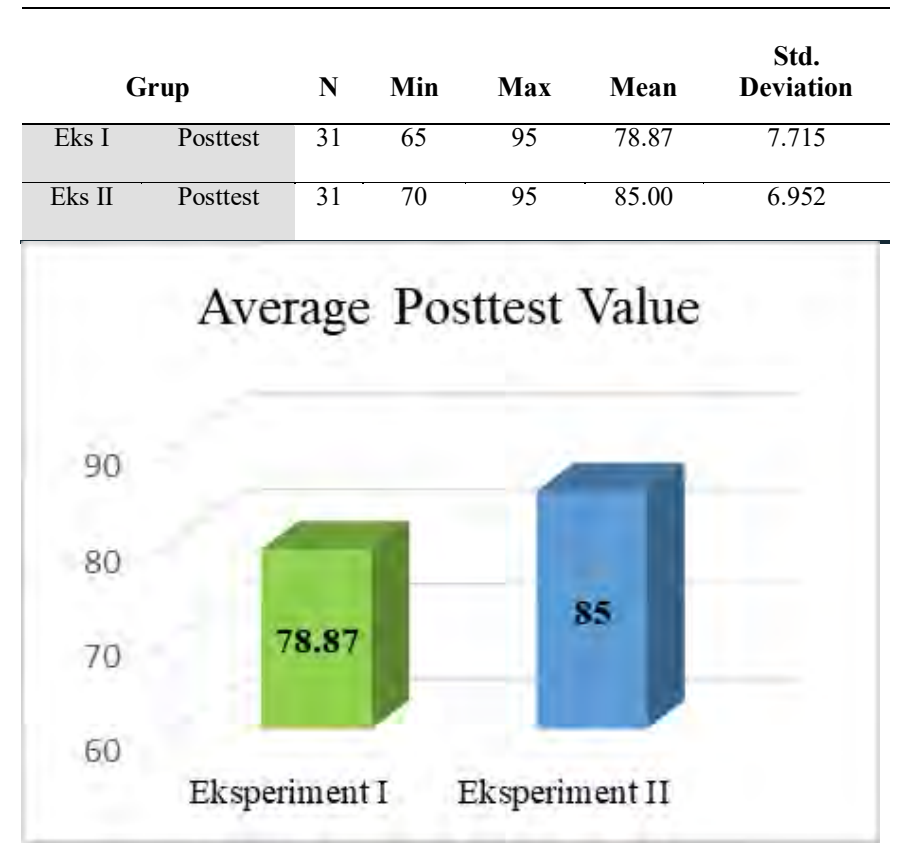

Fig 2. Average Student Posttest Value 
Based on Table 3, shows that the students' chemistry learning outcomes in the colloidal system material for the experimental class I after being taught with the Lectora Inspire assisted PBL model obtained an average posttest of 78.87 with the highest score of 95 and the lowest score of 65 while the experimental class II students after being taught with the Lectora Inspire assisted GI model, the posttest average was 85.00 with the highest score of 95 and the lowest score of 70 .

Based on the results of the pretest and posttest it can be seen the level of students' understanding of the colloidal system by calculating the gain value. Description of gain data for both classes can be seen in Table 4 .

TABLE 4. Description Of Data N-Gain Of Students Based On The Learning Model In The Experimental Class I And Experimental Class Ii

\begin{tabular}{ccccccc}
\hline Grup & & $\mathbf{N}$ & Min & Max & Mean & Std. Deviation \\
\hline Eks I & N-Gain & 31 & .40 & .88 & .6164 & .11549 \\
\hline Eks II & N-Gain & 31 & .43 & .90 & .6667 & .14478 \\
\hline
\end{tabular}

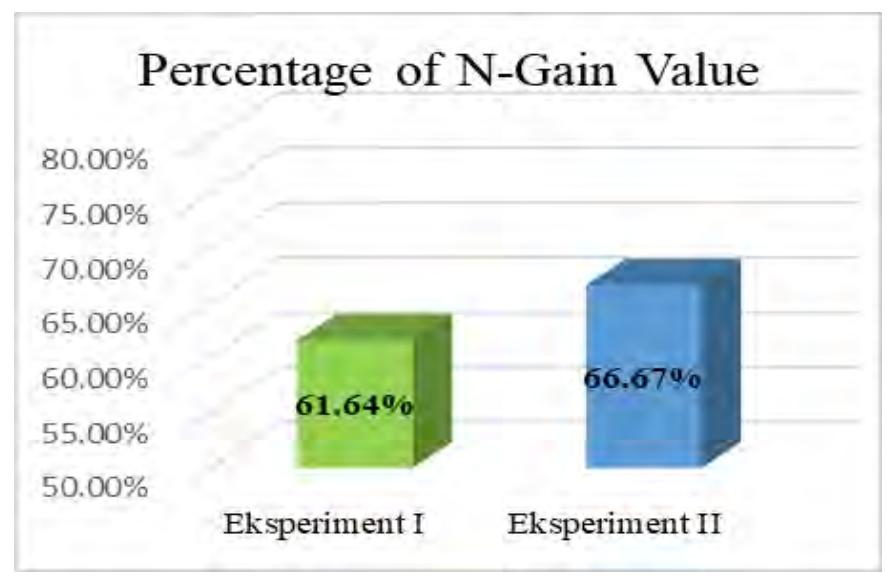

Fig 3. Percentage of Student's N-Gain Value

Based on Table 4 shows that the N-gain (cognitive value) of students in the colloidal system material for the group learned by the Lectora Inspire assisted PBL model obtained an average $\mathrm{N}$-gain of 0.6164 (average high), while for the group learned from the Lectora Inspire assisted GI model, the average $\mathrm{N}$-gain was 0.6667 (high average).

\section{Data on Student Scientific Attitudes Assessment}

Scientific attitude assessment is done to find out whether students in both classes already have a good scientific attitude. This is done so that learning runs smoothly. This data collection was carried out 1 time in each meeting and observed by 1 observer. The description of scientific attitude data in both classes can be seen in Table 5 .
TABLE 5. Description Of Data On The Value Of Scientific Attitudes Of Experimental Class I And Experimental Class Ii

\begin{tabular}{ccccccc}
\hline Group & N & Min & Max & Mean & $\begin{array}{c}\text { Std. } \\
\text { Deviation }\end{array}$ \\
\hline Eks I & $\begin{array}{c}\text { Scientific } \\
\text { attitude }\end{array}$ & 31 & 1.67 & 4.00 & 2.9677 & .61376 \\
\hline Eks II & $\begin{array}{c}\text { Scientific } \\
\text { attitude }\end{array}$ & 31 & 2.17 & 4.00 & 3.1398 & .53028 \\
\hline
\end{tabular}

From Table 5 shows that the scientific attitude of students for the experimental class I obtained an average score of 2.9677 with the highest value of 4.00 and the lowest value of 1.67. Whereas in the experimental class II, the average score was 3.1398 with the highest score of 4.00 and the lowest score of 2.17 .

Based on the data of scientific attitudes of students from a total of 62 students (31 from experimental class I and 31 from experimental class II) as many as 50 students had a high scientific attitude (as many as 24 from experimental class I and 26 from experimental class II) and as many as 12 students had an attitude scientific is low (as many as 7 from experimental class I and 5 from experimental class II).

The results of hypothesis testing using SPSS 24.0 program help are summarized in Table 6, and Table 7.

TABLE 6. Summary Of The Results Of The Independent Sample T-Test

\begin{tabular}{|c|c|c|c|c|}
\hline & & & \multicolumn{2}{|c|}{ Gain } \\
\hline & & & $\begin{array}{c}\text { Equal } \\
\text { variances } \\
\text { assumed }\end{array}$ & $\begin{array}{c}\text { Equal } \\
\text { variances not } \\
\text { assumed }\end{array}$ \\
\hline $\begin{array}{l}\text { Levene's } \\
\text { Test for }\end{array}$ & \multicolumn{2}{|l|}{$\mathrm{F}$} & 1.785 & \\
\hline $\begin{array}{l}\text { Equality of } \\
\text { Variances }\end{array}$ & \multicolumn{2}{|c|}{ Sig. } & .187 & \\
\hline \multirow{7}{*}{$\begin{array}{l}\text { t-test for } \\
\text { Equality of } \\
\text { Means }\end{array}$} & \multicolumn{2}{|l|}{$\mathrm{t}$} & -1.514 & -1.514 \\
\hline & \multicolumn{2}{|l|}{$\mathrm{df}$} & 60 & 57.176 \\
\hline & \multicolumn{2}{|c|}{ Sig. (2-tailed) } & .135 & .136 \\
\hline & \multicolumn{2}{|c|}{ Mean Difference } & -.05036 & -.05036 \\
\hline & \multicolumn{2}{|c|}{ Std. Error Difference } & .03326 & .03326 \\
\hline & \multirow{2}{*}{$\begin{array}{c}95 \% \\
\text { Confidence } \\
\text { Interval of } \\
\text { the } \\
\text { Difference }\end{array}$} & Lower & -.11690 & -.11696 \\
\hline & & Upper & .01617 & .01624 \\
\hline
\end{tabular}

From Table 6 it can be seen that the value of sig. (2-tailed) obtained is 0.135 . These results indicate that sig. $>0.05$ is $0.135>0.05$, meaning there is no significant difference between the two sample groups. 
TABLE 7. Summary Of The Results Of The Analysis Of Variance Analysis (Anava) Of Two Learning Model Pathways With A Scientific Attitude

\begin{tabular}{|c|c|c|c|c|c|}
\hline \multicolumn{6}{|c|}{ Dependent Variable: N-Gain } \\
\hline Source & $\begin{array}{l}\text { Type III Sum of } \\
\text { Squares }\end{array}$ & df & $\begin{array}{l}\text { Mean } \\
\text { Square }\end{array}$ & $\mathbf{F}$ & Sig. \\
\hline Corrected Model & $.258^{\mathrm{a}}$ & 3 & .086 & 6.170 & .001 \\
\hline Intercept & 13.358 & 1 & 13.358 & 956.718 & .000 \\
\hline Group & .008 & 1 & .008 & .540 & .465 \\
\hline Scientific attitude & .219 & 1 & .219 & 15.695 & .000 \\
\hline $\begin{array}{c}\text { Group * Scientific } \\
\text { attitude }\end{array}$ & .004 & 1 & .004 & .273 & .603 \\
\hline Error & .810 & 58 & .014 & & \\
\hline Total & 26.587 & 62 & & & \\
\hline Corrected Total & 1.068 & 61 & & & \\
\hline
\end{tabular}

Based on Table 7 it can be seen that the corrected model has a significance value of $0.001<0.05$ which means that the model used is valid. Intercept has a value of $0.000<0.05$, meaning that this intercept contributes significantly. In the group the significance value obtained is 0.465 which means that the group has no significant effect on the cognitive value of students. Scientific attitudes obtain a value of $0.000<0.05$ meaning that the scientific attitude has a significant influence on students' cognitive value. The significant value of the Group * Scientific attitude is used to determine whether or not the interaction between the learning model used with the scientific attitude category, from the table can be seen that the value obtained is $0.603>0.05$ meaning that there is no interaction between learning models with scientific attitude categories.

Based on the N-gain data analysis, it is known that the average increase in students 'cognitive chemistry value was learned using PBL model of 0.6164 so that the percentage of students' cognitive scores increased by $61.64 \%$ in the colloidal system material, while those learned using the GI model were obtained flat The improvement of students 'cognitive value was 0.6667 so that the percentage of students' cognitive value increase was $66.67 \%$. The percentage increase in cognitive values of students from both sample groups is not much different, meaning that there is no significant difference in the effect of PBL learning models with GI learning models on students' cognitive values. This is consistent with the results of the first hypothesis testing. These results can occur because when viewed from the syntax of PBL and GI learning models have similar steps. Such as problem orientation, investigating, until concluding so that the influence given is not much different.

If viewed from the results obtained in Table 6 shows that the significance value obtained is greater than 0.05 , that is $0.135>0.05$, then $\mathrm{HO}$ is accepted and $\mathrm{Ha}$ is rejected. This means that there is no significant difference in the cognitive value of students who are taught using PBL learning models assisted by Lectora Inspire media with the Lectora Inspireassisted GI learning model on colloidal system material.

Based on Table 7, sig. $0,000<0,05$ so $\mathrm{H} 0$ is rejected and $\mathrm{Ha}$ is accepted means that there are differences in the influence of high and low scientific attitude categories on students' cognitive values on colloidal system material. This is in accordance with the results of research conducted which states that there is a significant influence of scientific attitudes on student achievement in subject matter Acid, Basa, and Salt Students of Grade VII of Jaten N 1 Middle School [7].

Based on Table 7, sig. 0.603 $>0.05$ then H0 is accepted and $\mathrm{Ha}$ is rejected. This means that there is no interaction between the two learning models with scientific attitude categories in influencing students' cognitive values. This is consistent with the results of the study which showed that there was no interaction between the use of problem learning models and inquiry learning models with scientific attitudes towards learning achievement in the subject matter of basic chemistry law Boyolali 1 Public High School 2013/2014 Academic Year [8].

\section{CONCLUSION}

There were no significant differences in cognitive values of students who were taught using PBL learning models assisted by Lectora Inspire media with the Lectora Inspire media assisted GI learning model on colloid system material. There is a difference in the influence of high and low scientific attitude categories on students' cognitive values on colloidal system material. There is no interaction between the two learning models with scientific attitude categories in influencing students' cognitive values.

\section{References}

[1] P. Adetya, Nais,’Pengaruh Penerapan Model Inkuiri Terbimbing Terhadap Hasil Belajar dan Keterampilan Proses Sains Siswa Kelas XI SMA Institut Indonesia pada Materi Hidrolisis Garam. Semarang: Universitas Negeri Semarang”, 2015.

[2] R. Ramadhani, and B. A. Darussalam, "Pengaruh Model Pembelajaran Inkuiri Terbimbing terhadap Hasil Belajar Siswa pada Materi Koloid di SMAN 1 Lhoong Aceh Besar", Doctoral dissertation, UIN Ar-Raniry, 2017.

[3] T. A. Seftiana, "Pengembangan Modul Kimia Berbasis Problem Based Learning Pada Materi Koloid Sebagai Sumber Belajar Mandiri Siswa", Doctoral dissertation, Universitas Negeri Semarang, 2015.

[4] A. Winarsih, S. Mulyani, "Peningkatan profesionalisme guru IPA melalui Lesson Study dalam pengembangan model pembelajaraan PBI. Jurnal Pendidikan IPA Indonesia”, (1) :43-50,2012.

[5] A. Faruk, "Development of Interactive Learning Media Based Lectora Inspire in Discrete Method Course", Proceeding of International Conference On Research, Implementation And Education Of Mathematics And Sciences 2014, 2014.

[6] M. Bekmezci, I. Celik, I. Sahin, A. Kiray, and A. O. Akturk, “Analysis of Scientific Attitude, Computer Anxiety, Educational Internet Use, Problematic Internet Use, and Academic Achievement of Middle School Students According to Demographic Variables", Online Submission, 9(12), 4006-4014, 2015. 
[7] D. N. Anisa, M. Masykuri, S. Yamtinah, "Pengaruh model pembelajaran POE (Predict, Observe, and Explanation) dan sikap ilmiah terhadap prestasi belajar siswa pada materi asam, basa dan garam kelas VII semester 1 SMP N 1 Jaten tahun pelajaran 2012/2013", Jurnal Pendidikan Kimia, 2(2), 16-23, 2013.
[8] O, Magdalena, S. Mulyani, and E. S. Van Hayus, "Pengaruh Pembelajaran Model Problem Based Learning dan Inquiry Terhadap Prestasi Belajar Siswa Ditinjau dari Sikap Ilmiah pada Materi Hukum Dasar Kimia Kelas X SMAN 1 Boyolali Tahun Pelajaran 2013/2014”, Jurnal Pendidikan Kimia, 3(4), 162-169, 2014. 